\title{
Innovative Behaviour of High-Tech Internationalized Firms: Survey Results from Poland
}

\author{
Krzysztof Wach
}

\section{A B S T R A C T}

Objective: The aim of the article is to identify and verify the relationship between internationalization and innovativeness as well as innovative behaviour of high-tech businesses in Polish context.

Research Design \& Methods: A quantitative research design was employed. A survey was conducted on the sample of 263 firms operating in high-tech industries in Poland. To verify the assumed relationships statistical instruments were used, including descriptive statistics, Chi-Square test, the Kruskal-Wallis test and multivariate regression.

Findings: The level of innovativeness of investigated hi-tech firms was relatively high. Results suggest that the innovativeness of a business contributes to the intensification of the internationalization process of firms operating in high-tech industries. The regression model confirms the dependence of internationalization on three innovative behaviours, such as the general evaluation of innovativeness of the firm), the pace of innovation diffusion and the number of implemented innovations.

Implications \& Recommendations: Polish high-tech businesses seem to be relatively well internationalized, especially in comparisons to general business population. Policy makers should continue to support innovativeness of Polish economy, but especiaIly these industries which are highly innovative.

Contribution \& Value Added: The research presented in the article seems to be one of the first in Poland investigating into internationalization and innovation in hightech industries. The results are in line with the majority of empirical evidence worldwide. The preliminary link between innovation and internationalization among Polish high-tech businesses was confirmed.

\section{Article type: research article}

Keywords: innovation; innovativeness; i-models; international business; internationalization; international entrepreneurship

JEL codes: F23, 030, M16 Accepted: 3 September 2016

\section{Suggested citation:}

Wach, K. (2016). Innovative Behaviour of High-Tech Internationalized Firms: Survey Results from Poland. Entrepreneurial Business and Economics Review, 4(3), 153-165, DOI: http://dx.doi.org/10.15678/EBER.2016.040311 


\section{INTRODUCTION}

Currently, innovations are considered to be the heart of the present-day international entrepreneurship research (Onetti, Zuchella, Jones \& McDougall, 2012). Few previous decades have caused that the global economy has undergone a dramatic change, and the "new economic landscape requires a combination of entrepreneurship, innovation, and internationalization" (Hagen, Denicolai \& Zucchella, 2014, p. 111). Innovation, innovativeness and/or innovative resources are widely recognized as a major driver of firm internationalization either in traditional industries (Veglio \& Zuchella, 2015) and especially in high-tech industries (Spence \& Crick, 2006) or at least in knowledge-intensive industries (Bell, McNaughton, Young, Crick, 20013). Innovation is the key value creation and export performance either for large multinational enterprises (MNEs) (Cano-Kollmann, Cantwell, Hannigan, Mudambi \& Song, 2016) or for small and medium-sized enterprises (SMEs) (Kosała, 2015). Nevertheless, the recent empirical evidence and literature show that "the links between innovation and internationalization tend to be less clear" (Zuchella \& Siano, 2014) as it is quite difficult to capture empirically these relations.

The aim of the article is to identify and verify the links between internationalization and innovativeness as well as innovative behaviour of high-tech business in Polish realities. Empirical research is based on survey research. The article is designed in three conventional sections. The first section presents the literature review on the potential relationship between innovation and internationalization. The second section introduces the basic description of the material and methods used in the empirical study. The third section discussed the empirical results obtained on the sample of 263 firms operating in high-tech industries in Poland.

\section{LITERATURE REVIEW}

According to Schumpeter (1934), one of five forms of innovation is entering new markets, thus internationalization, as the expansion into a new foreign market or markets, can be considered innovation itself (more specifically, marketing innovation, while using a popular 4-element classification of innovation). Usually it is reported that the relation between innovation and internationalization dates back to 1970s (Szymura-Tyc, 2015, p. 70), at first at the macroeconomic level and then in business studies.

Rogers (1962, p. 8186) developed the process of the sequential adaptation of innovation (Innovation-adoption Process, IAP) on which innovation-related internationalization models are based. The introduction of innovation in stages models enabled to isolate the subgroup of innovation-related models which, in their primary assumptions, based on the behavioural theory and the phase internationalization process, therefore, are de facto a variety of stages models (Andersen, 1993, p. 212). The stress, however, is differently distributed as for the mechanism of the internationalization process and its explanation (Table 1). Innovation-related models are based on the sequential learning process, with regard to innovation or adaptation, and decisions of the firm about its internationalization are treated as innovations sensu largo. Various authors of various innovation-related models distinguish various stages of the internationalization process. Individual stages differ from each other, starting either from the lack of interest in inter- 
nationalization or export awareness, and as a rule ending with the exploration of farther foreign markets. Reid (1981, p. 104) states that "viewing exporting as innovation adoption gives us richer insight into how exporting is initiated and how it is developed". The innovation-based stages models treat internationalization per se as a process of innovation, especially as a learning process - internationalization by learning (Andersen \& Kheam, 1998).

Table 1. The comparison of stages models (U-model) with innovation-based models (I-model)

\begin{tabular}{|c|c|c|c|}
\hline \multicolumn{2}{|r|}{ Criterion } & U-model & I-models \\
\hline \multicolumn{2}{|c|}{ Types of scientific explanation } & \multicolumn{2}{|c|}{ Genetic historicism } \\
\hline \multirow{2}{*}{$\begin{array}{l}\text { Analytical } \\
\text { assumptions }\end{array}$} & Unit of analysis & $\begin{array}{c}\text { No restrictions } \\
\text { (SMEs, Large enterprises) }\end{array}$ & SMES \\
\hline & Time & Unlimited & Limited \\
\hline \multirow[b]{2}{*}{ Causation } & Model type & Causative cycles & Explanatory chain \\
\hline & Explanatory variables & $\begin{array}{l}\text { One variable: knowledge } \\
\text { of the enterprise }\end{array}$ & $\begin{array}{l}\text { A lot of variables, mostly } \\
\text { concerning organization- } \\
\text { al factors }\end{array}$ \\
\hline \multirow{3}{*}{$\begin{array}{l}\text { Scientificity / } \\
\text { Utilitarity }\end{array}$} & $\begin{array}{l}\text { Assumptions with regard } \\
\text { to enterprise behaviour }\end{array}$ & \multicolumn{2}{|c|}{$\begin{array}{l}\text { Based on behavioural theories, incremental decision- } \\
\text { making process with no or little impact of competitive } \\
\text { and market factors }\end{array}$} \\
\hline & $\begin{array}{l}\text { Correctness of defining } \\
\text { the variables }\end{array}$ & $\begin{array}{l}\text { Examples of possible } \\
\text { indicators, no operating } \\
\text { definitions }\end{array}$ & $\begin{array}{l}\text { Unclear arguments for } \\
\text { the classification of } \\
\text { procedures or operation- } \\
\text { alization of explanatory } \\
\text { variables }\end{array}$ \\
\hline & $\begin{array}{l}\text { Accuracy of delimitation } \\
\text { between stages }\end{array}$ & $\begin{array}{l}\text { Considerable generality } \\
\text { and ambiguity }\end{array}$ & $\begin{array}{l}\text { Basically intuitive argu- } \\
\text { mentation and reasoning }\end{array}$ \\
\hline \multicolumn{2}{|c|}{ Usefulness / Intuitiveness } & \multicolumn{2}{|c|}{$\begin{array}{l}\text { Axiomatic logics. Useless for the needs of manage- } \\
\text { ment and government policy. }\end{array}$} \\
\hline \multicolumn{2}{|c|}{$\begin{array}{l}\text { Conformity between: } \\
\text { - theory and operationalization } \\
\text { - conceptual and operating definitions }\end{array}$} & Unclear & $\begin{array}{l}\text { Some discrepancies, no } \\
\text { testing of validity }\end{array}$ \\
\hline \multicolumn{2}{|c|}{$\begin{array}{l}\text { Specification of variables adopted to de- } \\
\text { termine the impact on the development } \\
\text { process }\end{array}$} & $\begin{array}{l}\text { No variables except for } \\
\text { causative cycles }\end{array}$ & $\begin{array}{l}\text { Lack of complete list of } \\
\text { variables, unclear argu- } \\
\text { mentation why and how } \\
\text { variables should differ } \\
\text { between stages }\end{array}$ \\
\hline \multicolumn{2}{|c|}{ Empirical setting } & $\begin{array}{l}\text { Case studies: measure- } \\
\text { ment of independent } \\
\text { variables based on the } \\
\text { observation of depend- } \\
\text { ent variables }\end{array}$ & $\begin{array}{l}\text { Cross-section analyses, } \\
\text { unclear causality of } \\
\text { internationalization } \\
\text { phases from their deter- } \\
\text { minants }\end{array}$ \\
\hline \multicolumn{2}{|c|}{ Tautologies } & $\begin{array}{l}\text { Some difficulties in } \\
\text { delimitation of theoreti- } \\
\text { cal concepts }\end{array}$ & $\begin{array}{l}\text { In some cases independ- } \\
\text { ent and dependent } \\
\text { variables are almost } \\
\text { identical }\end{array}$ \\
\hline \multicolumn{2}{|c|}{ Testing alternative explanatory variables } & \multicolumn{2}{|c|}{ none } \\
\hline
\end{tabular}

Source: own compilation based on Andersen (1993, p. 221 \& 226). 
Literature and various empirical evidence reveal a bipolar dependence, innovation can impact internationalization, but also internationalization can influence innovation, thus there are two main streams of research (Daszkiewicz, 2016, p. 105, Szymura-Tyc, 2015, p. 85):

1. Innovation as the cause. Innovativeness and innovative behaviour of firms cause (faster or better) internationalization.

2. Innovation as the effect. Internationalization and international experience stimulate innovative behaviour of the firm.

In the literature there is an ongoing debate on the role of innovations and the links between innovation and internationalization and sometimes the empirical results are quite contrary. Based on the sample of 299 internationalized Finish firms and using a cluster analyses Kyläheiko et al. (2011) found that most of the firms were replicators (79.8\%), not innovators (20.2\%), and distinguished four clusters, namely (i) international replicators $-29.3 \%$ of the sample, (ii) domestic replicators $-50.5 \%$, (iii) domestic innovators $-11 \%$, (iv) international innovators $-9.2 \%$. Innovative capabilities, especially technological ones, are a major driver of international growth of the firm (Pla-Barber \& Alegre, 2007). As for various types of innovations, the most important in the internationalization process are product innovations, or generally technological innovations. It seems that there is a positive relationship between product innovation and export performance as the basic mode of internationalization (Cassiman \& Golovko, 2011). Innovation can be classified as hard and soft, what is more the innovative behaviour of the entrepreneur, especially in case of SMEs, also impacts the international performance of the business (Denicolai, Hagen \& Pisoni, 2015). High-tech businesses, especially small technologybased enterprises (STEs) are international from the inception and called born globals (Kuivalainen, Saarenketo \& Puumalainen, 2012; Zou \& Ghauri, 2010), and it is a clear evidence that there is a link between innovations (knowledge, high-technology) and internationalization, at least in case of high-tech industries. Also Li, Qian and Qian (2012) confirmed that technological intensity is positively correlated with the early internationalization (born globals). Li, Qian and Qian (2015) proved that radical innovations are positively correlated with internationalization, as small young technology-based entrepreneurial firms (SYTEFs) that "generate radical innovation are more likely to internalize their foreign operations". Chetty and Stangl (2010) confirmed that internationalized businesses with limited network relationships have incremental internationalization and innovation, but those with diverse network relationships exhibit radical internationalization and innovation. Literature on the role of innovation in international business is very diverse and rich and deals with many detailed aspects like licencing or research and development (R\&D). Pinkwart and Proksch (2014) confirmed that going international is positively related with havening patents or licences. The above mentioned variables can be put together and integrated into the basic concept of international entrepreneurship (Wach, 2015, p. 19), which can result in the theoretical modelling of innovative internationalization of the firm (Figure 1).

Both, the literature studies, and especially the review of various empirical studies resulted in the following hypothesis to be testes in the empirical reality in Poland: 
H: Innovativeness and innovative behaviour of a business contributes to the intensification of the internationalization process of the firm operating in the high-technology industries.

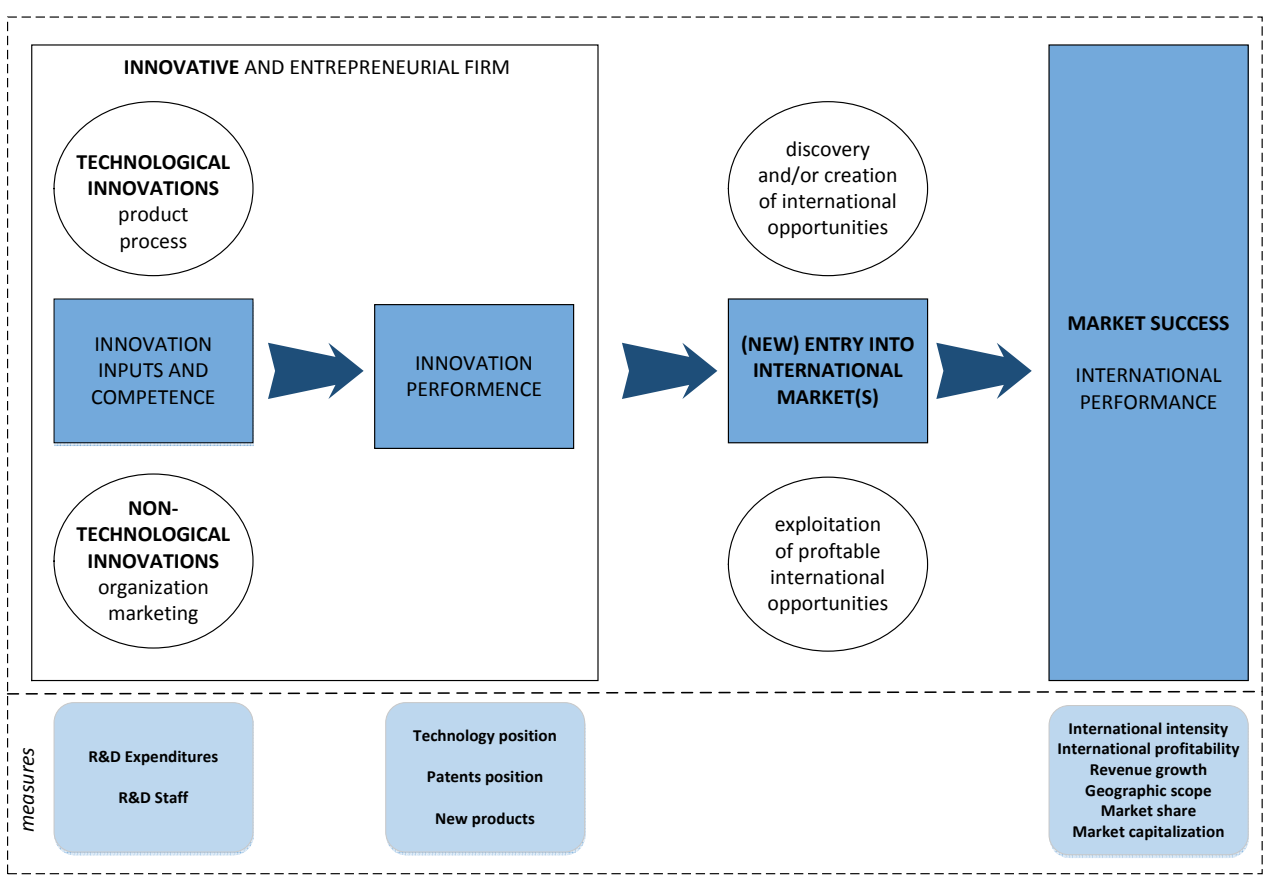

Figure 1. The theoretical modelling of innovative internationalization in international entrepreneurship

Source: own study based on Wach (2015, p. 19) and Gerybadze (2010, p. 15).

\section{MATERIAL AND METHODS}

To identify and verify the links between innovation and internationalization of hightechnology businesses in Poland survey research was employed. The study was conducted at the end of 2015 using Computer Assisted Telephone Interviewing (CATI). Stratified sampling has been selected according to the following criteria (Daszkiewicz, 2016, p. 124):

- firms performing any international activities (at least exports),

- firms belonging to one of the given classes of business activity (NACE), being classified as high-tech or medium-high-tech industries,

- firms fulfilling at least one out of the following three criteria:

a) obtaining patents or signing licensing agreements in the areas identified as hightech,

b) employing highly qualified personnel in terms of science and technology, 
c) conducting industrial research, research and development (R\&D) activities to prepare these studies and work to implement in the economy.

Based on the above mentioned criteria, the target population was selected, and the survey questionnaire was directed to 4075 businesses from the database, of which 857 businesses, in fact were not eligible for the study, or did not have in the database the current phone number, so the net population was only 3218 of internationalized hightech firms. In the course of surveying we obtained 263 fully completed questionnaires (the return rate was $8.2 \%$ ), suitable for further statistical processing, as a basis for inferring.

The study uses six different variables (one measuring the internationalization level and five measuring innovativeness and innovative behaviour) such as:

- the transnationality index (TNI) expressed as a percentage (from 0 to $100 \%$ ),

- the pace of innovation diffusion measured on 7-point Likert scale (DiffPace),

- the number of implemented innovation from 0 to 8 (InnoNumb),

- the innovation scope (business-level, regional, country-wide, worldwide innovations),

- the innovation types (product, process, organizational, marketing innovations),

- the innovation index (INNO) as a continuous variable (1-100\%) and an interval variable (low, moderate, high innovators).

The transnationality index (TNI) was calculated as the average of foreign assets, sales and employment to the total ones and being expressed as a percentage based on the formula:

where:

$$
T N I=\frac{\frac{A_{F}}{A_{T}}+\frac{S_{F}}{S_{T}}+\frac{E_{F}}{E_{T}}}{3} * 100[\%]
$$

$$
\begin{aligned}
& A_{T} \text { - total assets; } \\
& A_{F} \text { - foreign assets; } \\
& S_{T} \text { - total sale; } \\
& S_{F} \text { - foreign sales; } \\
& E_{T} \text { - total employment; } \\
& E_{F} \text { - foreign employment. }
\end{aligned}
$$

In order to evaluate the real level of innovativeness of the investigated firms, there was a need to create one indicator expressing the innovative behaviour of business. The innovation index (INNO) enabled to evaluate the innovativeness of the responding firms. This synthetic indicator uses two basic dimensions of innovations, namely (i) the range of innovations measured by their types and numbers and (ii) the scope of innovations measured on the tradition 4-category scale (in numbers expressed from 1 to 4). Each innovation was able to provide from 1 to 4 points. 8 different cases of various innovations enabled to provide up to 32 points. The innovation index, as the overall indicator of innovation evaluation, was constructed by the sum of the values at each of the cases (by multiplying the range and the scope of innovations), and then divided by the sum of the maximum achievable points. Ultimately, it resulted in an average total score, standardized in the range of 0 to 1 (expresses as the percentage in the range from 0 to 100). The 
following weights were adopted: $(0 ; 25>-$ low innovators; $(25 ; 75>-$ moderate innovators; $(76 ; 100>-$ high innovators.

The statistical calculations were made by the use of the statistical software Statisti$\mathrm{ca}^{\circledR} \mathrm{PL}$ v. 12.5. In the empirical study, the level of the statistical significance (alpha or $\alpha$ ) for statistical hypotheses testing was considered as 0.05 . To verify the assumed relations statistical instruments were used such as descriptive statistics, Chi-Square test, the Kruskal-Wallis test, the linear Pearson correlation and the multivariate regression.

\section{RESULTS AND DISCUSSION}

As for the size of the investigating businesses, the sample was diversified, and included: $9 \%$ of microenterprises, $26 \%$ of small enterprises, $47 \%$ of medium-sized enterprises and $18 \%$ of large enterprises. The share of enterprises belonging to the SME sector of the surveyed businesses is $82 \%$ (216 enterprises), while the share of large enterprises is $18 \%$ (47 enterprises). Businesses were located in all 16 regions of Poland, with a clear overrepresentation came from three regions: mazowieckie, ślqskie and wielkopolskie. Among the surveyed firms, over $75 \%$ had exclusively domestic capital, and less than $15 \%$ of the surveyed businesses declared that foreign ownership of assets is $100 \%$.

All investigated businesses implemented within the previous 3 years at least one type of innovation. Respondents were given a list of 8 different innovations, to be more specific there were two different innovations of each of 4 basic types of innovations (Figure 2). Altogether it was possible to declare 8 different innovations. Between 1 and 3 innovations were implemented by 26.23 investigated firms, while 4 of 5 innovations were introduced by $33.45 \%$ of business and the highest number of innovations, between 6 and 8 , were declared by 40.32 of the responding firms. The overall level of innovation implementation was rather high, comparing to general empirical studies of internationalized businesses, but as the study included high-tech companies, so the high level cannot be surprising. The innovativeness level of Polish internationalized businesses operating in various industries (sample of 293) conducted by Szymura-Tyc (2015, pp. 165-170) was a bit lower. Almost all investigated firms implemented product innovation (257 out of 263), while organizational innovations were the least popular (152 out of 263). Either process or marketing innovations were also quite popular among the responding firms (respectively 204 and 222).

According to the theory of innovation, the scope of innovation is important while judging innovation behaviour of firms. All investigated business implemented at least one type of innovation, however its scope was very diversified:

a) $14.8 \%$ investigated firms implemented business-level innovations (39 cases),

b) $4.2 \%$ investigated firms implemented regional level innovations (11 cases),

c) $18.3 \%$ investigated firms implemented country-wide innovations (48 cases),

d) $62.7 \%$ investigated firms implemented worldwide innovations (165 cases ).

The scope of the declaring innovations is indeed very optimistic, especially taking into account the types of the implemented innovations (Figure 3). The product innovations, which are crucial for high-tech firms, were the most frequently implemented in the global scale, which means they were new to the world. 


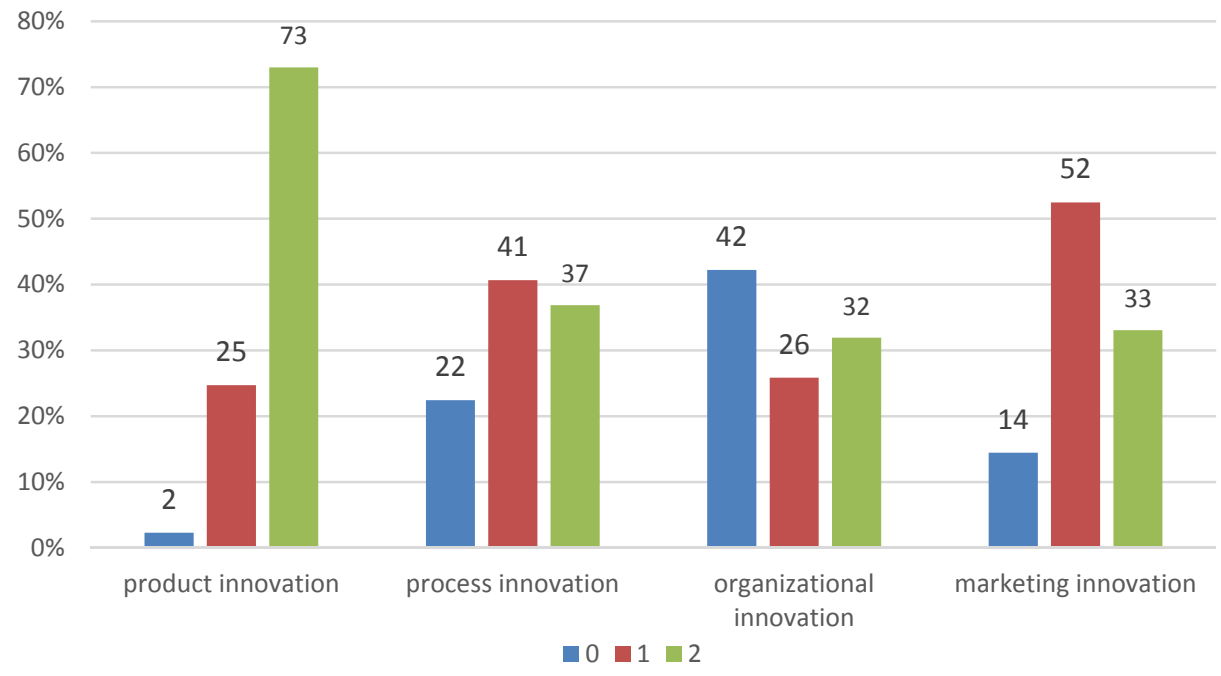

Figure 2. Number of implemented innovations by their types among the investigated businesses (in \%)

Note: The numbers do not sum up to $100 \%$ as respondents could select more than one answer. Source: own calculations based on the survey $(n=263)$.

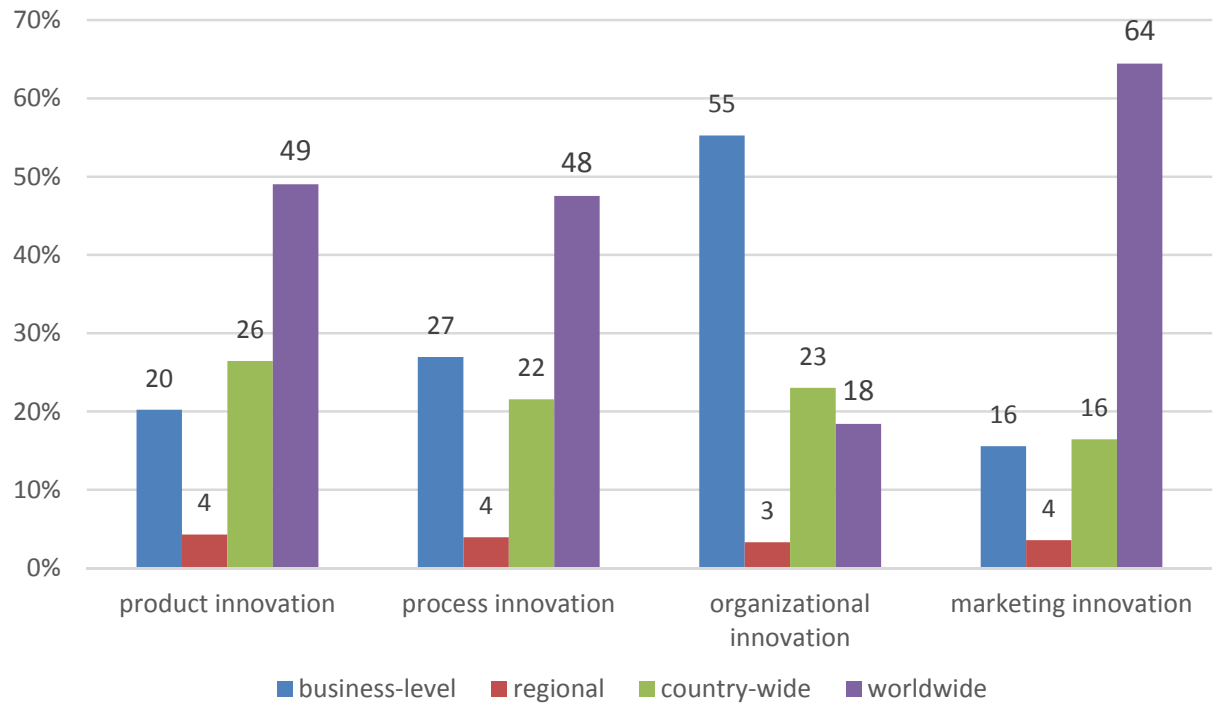

Figure 3. Scope of implemented innovations by their types among the investigated businesses (in \%)

Note: The numbers might not sum up to $100 \%$ due to rounding. Source: own calculations based on the survey $(n=263)$. 
Rating of the business innovativeness ranges of continuous values from the both sides closed interval in the range of $\langle 1,100\rangle$. The innovation index of investigated business ranged from 3.12 to 100 (Table 2). Based on the mean, the median, and the mode, it is obvious that the innovation behaviour of investigated firms was average in most cases. Only one fourth of the firms, exceeded its level amounted to 62.50 and these companies can be considered hyper innovative.

Table 2. Descriptive statistics of innovation index (INNO) of the investigated businesses

\begin{tabular}{|c|c|c|c|c|c|c|c|c|}
\hline Mean & Median & Mode & $\begin{array}{c}\text { Frequency } \\
\text { of Mode }\end{array}$ & Minimum & Maximum & $\begin{array}{c}\text { Lower } \\
\text { Quartile }\end{array}$ & $\begin{array}{c}\text { Upper } \\
\text { Quartile }\end{array}$ & Std. Dev. \\
\hline 43.91 & 40.62 & 37.50 & 24 & 3.12 & 100 & 25 & 62.50 & 24.16 \\
\hline
\end{tabular}

Source: own calculations based on the survey and Statistica $12.5(n=263)$.

As suggested by prior research there is a theoretical assumption that there is a dependence between the internationalization and innovativeness of firms. The linear Person correlation value between TNI (internationalization level of firms) and INNO (the innovation index of firms) is only 0.31 significant at $p<0.05$, which means the average correlation between these variables. Also Szymura-Tyc $(2015$, p. 177) obtained very similar results based on the sample of 293 internationalized business operating in various industries $(r=0.302, p<0.001)$. Taking the 4-category innovation index and using the Kruskal-Wallis test the dependence between the variables of TNI and INNO was also confirmed (Chi-Square $=10.65, \mathrm{df}=2, \mathrm{p}=0.0049 ; \mathrm{H}(2,261)=969935, \mathrm{p}=0.0078$ ). It was also confirmed by the median test, and the mean ranks for groups were as follows: 118 , 130,173 . Studying the "box \& whisker" plot it is noticeable that the better innovator is, the higher TNI value it receives (Figure 4). TNI values was the highest for so called high innovators, and the lowest for the low innovators. Therefore, the hypothesis was confirmed, according to which the innovativeness of a business contributes to the intensification of the internationalization process of the firm operating in the high-technology industries.

In order to search for deeper relationships, multiple regression was used. Although the $p$-value means very strong presumption against neutral hypotheses, the model explains only $5.6 \%$ of the dependence of TNI on three innovative behaviours, such as (i) the innovation index (as the general evaluation of innovativeness of the firm), (ii) the pace of innovation diffusion and (iii) the number of implemented innovations. If the innovation index will increase of 1 p.p., TNI will increase in average of 5.47 p.p. ceteris paribus. What can be interesting is the fact that if the number of innovation will increase of 1 p.p., TNI will decrease of 1.98615 p.p. Despite the awkward outlook, these results can be explained quite easily, as we can assume, as the investigated firms introduced between 1 and 8 innovations, so some of them were inessential or even unnecessary. Probably organizational and/or marketing innovations, except for being costly, didn't supported the internationalization process, as we could assume. 
Table 3. Regression Summary for Dependent Variable of TNI

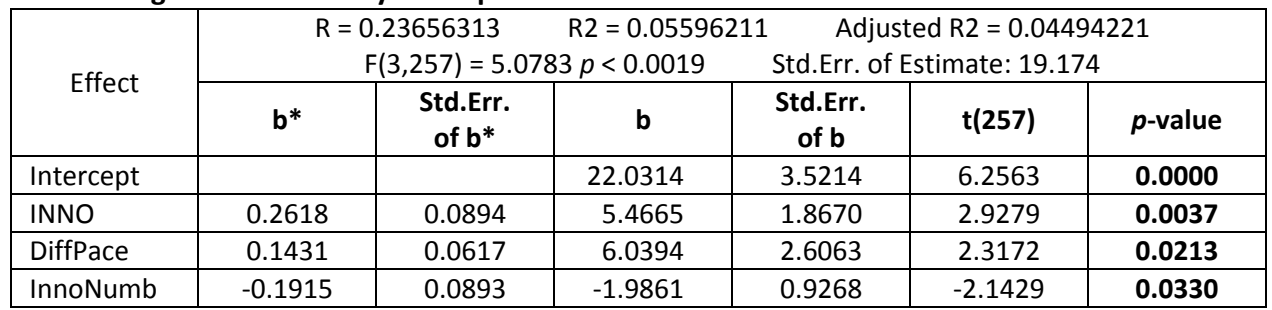

Source: own calculations based on the survey and Statistica $12.5(n=263)$.

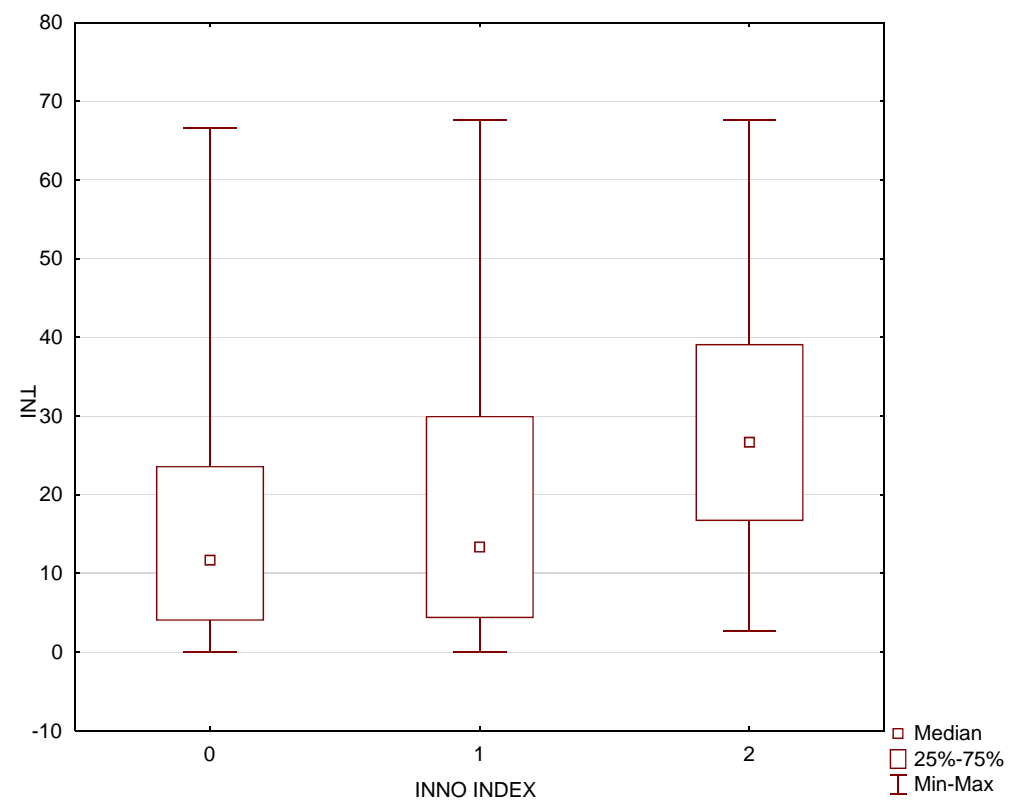

Figure 4. Boxplot by group for the variables TNI and INNO INDEX

Note: 0 - low innovators, 1 - medium innovators, 2 - high innovators.

Source: own calculations based on the survey $(n=263)$.

\section{CONCLUSIONS}

Like all research, this study is not without some notable limitations. First of all, the research sample is not representative for the whole population, thus it is not possible to absolutize the result over the whole population of Polish businesses of high-tech industries, but are quite close to generalization. Secondly, future studies should seek to develop longitudinal research designs.

Based on the statistical calculations presented in the article, the following conclusions can be drawn: 
1. The overall level of innovation implementation among the investigated firms was rather high, comparing to general empirical studies of internationalized businesses, but as the study included high-tech companies, so the high level cannot be surprising.

2. Almost all investigated firms implemented product innovation, as for high-tech industries this can be obvious.

3. Most of the investigated businesses implemented worldwide innovations, as the widest range of 4-category classification, and again for high-tech industries this is rather expected.

4. The hypothesis stating that the innovativeness of a business contributes to the intensification of the internationalization process of the firm operating in the hightechnology industries, was confirmed (linear Pearson correlation, Kruskal-Wallis test). The higher level of TNI was observed among high innovators and the lowest among low innovators.

5. The regression model showed the dependence of TNI on three innovative behaviours, such as the innovation index, the diffusion of innovation pace and the number of implemented innovation.

The research presented in the article seems to be one of the first in Poland investigating into internationalization and innovation in high-tech industries. The results are in line with the majority of empirical evidence worldwide. The preliminary links between innovation and internationalization among Polish high-tech businesses were confirmed. Further research should seek the links and dependences between technological as well as non-technological innovations and the internationalization intensity.

The empirical results have also great importance for policy makers, as the illustration of Polish high-tech businesses seem to be relatively well internationalized, especially in comparisons to general business population. Policy makers should continue to support innovativeness of Polish economy, but especially these industries which are highly innovative.

\section{REFERENCES}

Andersen, O. (1993). On the Internationalization Process of Firms: A Critical Analysis. Journal of International Business Studies, 24(2), 209-231.

Andersen, O., \& Kheam, L.S. (1998). Resource-based theory and international growth strategies: an exploratory study. International Business Review, 7(2), 163-184.

Bell, J., McNaughton, R., Young, S., \& Crick, D. (2003). Towards and integrative model of small firm internationalization. Journal of International Entrepreneurship, 1(4), 339-362.

Cano-Kollmann, M., Cantwell, J., Hannigan, T.J., Mudambi, R., \& Song, J. (2016). Knowledge connectivity: An agenda for innovation research in international business. Journal of International Business Studies, 47(3), 255-262.

Cassiman, B., \& Golovko, E. (2011). Innovation and internationalization through exports. Journal of International Business Studies, 42(1), 56-75.

Chetty, S.K., \& Stangl, L.M. (2010). Internationalization and innovation in a network relationship context. European Journal of Marketing, 44(11/12), 1725-1743. 
Daszkiewicz, N. (2016). Internacjonalizacja przedsiębiorstw działająych w branżach high-tech. Warszawa: PWN.

Denicolai, S., Hagen, B., \& Pisoni, A. (2015). Be international or be innovative? Be both? The role of the entrepreneurial profile. Journal of International Entrepreneurship, 13(4), 390-417.

Gerybadze, A. (2010). R\&D, Innovation and Growth: Performance of the World's Leading Technology Corporations. In: A. Gerybadze, U. Hommel, H.W. Reiners, D. Thomaschewski (Eds.), Innovation and International Corporate Growth. Berlin - Heidelberg: Springer.

Hagen, B., Denicolai, S., \& Zuchella, A. (2014). International entrepreneurship at the crossroads between innovation and internationalization. Journal of International Entrepreneurship, 12(2), 111-114.

Kosała, M. (2015). Innovation Processes as a Stimulant of Internationalization Process of Firms. Entrepreneurial Business and Economics Review, 3(2), 65-84. doi: 10.15678/EBER.2015. 030206

Kuivalainen, O., Saarenketo, S., \& Puumalainen, K. (2012). Start-up patterns of internationalization: a framework and its application in the context of knowledge-intensive SMEs. European Management Journal, 30(4), 372-385.

Kyläheiko, K., Jantunen, A., Puumalainen, K., Saarenketo, S., \& Tuppura, A. (2011). Innovation and internationalization as growth strategies: The role of technological capabilities and appropriability. International Business Review, 20(5), 508-520.

Li, L., Qian, G., \& Qian, Z. (2012). Early internationalization and performance of small high-tech born-globals. International Marketing Review, 29(5), 536-561.

Li, L., Qian, G., \& Qian, Z. (2015). Should Small, Young Technology-Based Firms Internalize Transactions in Their Internationalization?. Entrepreneurship Theory and Practice, 39(4), 839-862.

Onetti, A., Zuchella, A., Jones, M., \& McDougall, P. (2012). Entrepreneurship and strategic management in new technology based companies. Journal of Management and Governance, 16(3), 5-22.

Pinkwart, A., \& Proksch, D. (2014). The Internationalization Behavior of German High-Tech Startups: An Empirical Analysis of Key Resources. Thunderbird International Business Review, 56(1), 43-53.

Pla-Barber, J., \& Alegre, J. (2007). Analysing the link between export intensity, innovation and firm size in a science-based industry. International Business Review, 16(3), 275-293.

Reid, S.D. (1981). The Decision-Maker and Export Entry and Expansion. Journal of International Business Studies, 12(2), 101-112.

Rogers, E.M. (1983). Diffusion of innovations. New York - London: The Free Press.

Schumpeter, J.A. (1934|2008). The Theory of Economic Development: An Inquiry into Profits, Capital, Credit, Interest and the Business Cycle. Transl. by R. Opie. New Brunswick - London: Transaction Publishers.

Spence, M., \& Crick, D. (2006). A comparative investigation into the internationalization of Canadian and UK high-tech SMEs. International Marketing Review, 23(5), 524-548.

Szymura-Tyc, M. (2015). Internacjonalizacja, innowacyjność i usieciowienie przedsiębiorstw: podejście holistyczne. Warszawa: Difin.

Veglio, V., \& Zuchella, A. (2015). Entrepreneurial firms in traditional industries. Does innovation matter for international growth?. Journal of International Entrepreneurship, 13(2), 138-152.

Wach, K. (2015). Entrepreneurial Orientation and Business Internationalization Process: The Theoretical Foundations of International Entrepreneurship. Entrepreneurial Business and Economics Review, 3(2), 9-24. doi: 10.15678/EBER.2015.030202 
Zou, H., \& Ghauri, P. (2010). Internationalizing by learning: the case of Chinese high-tech new ventures. International Marketing Review, 27(2), 223-244.

Zucchella, A., \& Siano, A (2014). Internationalization and innovation as resources for SME growth in foreign markets: a focus on textile and clothing firms in the Campania Region. International Studies of Management and Organization, 44(1), 21-41.

\section{Author}

\section{Krzysztof Wach}

Associate Professor of the Cracow University of Economics (Poland). Habilitated doctor of economics (DEcon), PhD in management, specialist in international entrepreneurship, author of several books and over 150 scientific articles, editor-in-chief of the scientific quarterly 'Entrepreneurial Business and Economics Review' (Poland) and the scientific biannual 'International Entrepreneurship' (Poland), member of editorial boards of several scientific journals, including 'Business Excellence' (Croatia), 'Studia Negtia' (Romania), 'Entrepreneurship - Education' (Poland); Journal of Management and Business Administration - Central Europe (Poland); in the years 2012-2014 an OECD and the European Commission national expert for entrepreneurship, participant of various international education and research projects (e.g. Jean Monnet, Atlantis, International Visegrad Fund IVF, Central European Initiative CEI), visiting professor in various American and European universities, including Grand Valley State University (Grand Rapids, USA), Roosevelt University (Chicago, USA), University of Detroit Mercy (Detroit, USA), Loyola University Chicago (Chicago, USA), Northumbria University (Newcastle, UK), University College London (UK), Technical University of Cartagena (Cartagena, Spain).

Correspondence to: Prof. UEK dr hab. Krzysztof Wach; Cracow University of Economics; Faculty of Economics and International Relations; Department of International Trade; ul. Rakowicka 27, 31-510 Kraków, Poland; e-mail: wachk@uek.krakow.pl

\section{Acknowledgements and Financial Disclosure}

The article came into being within the research project OPUS 6 entitled Internationalization of small and medium-sized enterprises operating in high-tech industries, which has been funded by the National Science Centre (NCN) on the basis of the decision no. DEC-2013/11/B/HS4/02135 in the years 2014-2017.

\section{Copyright and License}

This article is published under the terms of the Creative Commons Attribution - NonCommercial - NoDerivs (CC BY-NC-ND 3.0) License http://creativecommons.org/licenses/by-nc-nd/3.0/ 
